\author{
Janusz Myszczyszyn \\ West Pomeranian University of Technology in Szczecin \\ Faculty of Economics \\ e-mail: jmyszczyszyn@zut.edu.pl \\ ORCID: 0000-0001-9578-5741
}

\title{
COINTEGRATION ANALYSIS BETWEEN ECONOMIC GROWTH AND THE NUMBER OF GRANTED PATENTS BASED ON THE EXAMPLE OF THE GERMAN ECONOMY
}

\author{
DOI: $10.15611 /$ pn.2020.9.07 \\ JEL Classification: O11, O47, N11 \\ (C) 2020 Janusz Myszczyszyn \\ This work is licensed under the Creative Commons Attribution-ShareAlike 4.0 International \\ License. To view a copy of this license, visit http://creativecommons.org/licenses/by-sa/4.0/ \\ Quote as: Myszczyszyn, J. (2020). Cointegration analysis between economic growth and the \\ number of granted patents based on the example of the German economy. Prace Naukowe \\ Uniwersytetu Ekonomicznego we Wrocławiu, 64(9).
}

\begin{abstract}
The main purpose of the article was to use the Granger cointegration test to confirm the long-term relationship between the level of economic growth in Germany and the number of granted patents, including the so-called economically valuable patents. The empirical analysis was based on available statistical data on the level of economic growth (seven time series) and the number of patents received and valuable patents in the period 1872-1913. In addition to estimates of Pearson's correlation coefficients, tests for checking the unit root: ADF and KPSS, were used. They indicated that all the analysed time series are integrated in the first stage I(1), which enabled the use of the Engle-Granger cointegration test. The obtained research results did not confirm the long-term correlation between the level of economic growth in Germany and the number of granted patents, including the so-called economically valuable patents.
\end{abstract}

Keywords: Engle-Granger cointegration, granted patents, economic growth of Germany.

\section{Introduction}

German countries, politically dysfunctional in the pre-industrial period, were affected by pauperism. At the end of the 18th and the beginning of the 19th century, their underdeveloped economy did not need many workers, the lack of permanent employment was widespread and the wages were so low that those who periodically found work, and their families, could hardly survive (Tilly, 1990). 
The German economy took off around 1850, which resulted in transformations in the economy and society, as well as a continuous increase in their global product. Already in 1834, German countries, by establishing the German Customs Association, abolished internal customs borders while pursuing a uniform customs policy towards foreign countries (Myszczyszyn, 2011). At the same time, the rail network, heavy industry, electro-machinery, chemical industries, etc. were gradually expanded, including an effective education system (also at university level). Political reunification (1871) showed that Germany was an important economic partner in the international arena (Metz and Watteler, 2002, pp. 17-18).

The economic success of Germany is specific because the country belonged to a group of poor countries in terms of mineral resources, and a special role was played by the increase in the total factor productivity (TFP). Metz and Watteler pointed out that in 1870-1973 the share of TFP growth in Germany's economic growth was about $42 \%$. In turn, Burhop estimates that in 1851-1913 the increase in TFP was the cause of about a $25 \%$ increase in industrial production (Burhop, 2010, p. 925). In this context, changes in human capital and the level of R\&D expenditure not only on the part of the state but also on the part of enterprises have become an important element, and a measurable indicator in this was the legal introduction of patent protection resulting in an increase in the number of granted patents.

Patents enabling the protection of inventions for many companies were of decisive importance as part of their strategic and operational activities for the protection of their branches of the national economy, being an important input factor for the development of innovation in the economy.

It should be noted that in the politically dysfunctional German states, local laws and ordinances were issued in the first half of the 19th century, the task of which was to protect inventions by granting patents with limited validity (Bielig, 2013, pp. 151-152). After the reunification of Germany, the Patent Act adopted by the Reichstag, signed by Emperor Wilhelm I (Das Reichspatentgesetz) on 25 May 1877, was an important step for the entire German economy, and significant in building the "made in Germany" brand. It is worth mentioning that in the initial phase of economic development (up to 1870), Germany, without incurring expenditure on research and development, effectively imitated foreign (e.g. English, Belgian) experience in the sphere of the development of individual branches of the national economy (Myszczyszyn, 2019, p. 121). The progressive industrialisation increased the awareness of legal protection of intellectual property, which, under certain conditions, led to an increase in the competitiveness of the domestic economy, being a safeguard against external competition.

Patent protection resulted in a growing interest on the part of the business sector to provide funds for research and development (Streb, Wallusch, and Yin, 2007). Introducing the Act, from today's perspective also meant the state's readiness to pursue an active economic policy, including supporting knowledge and education, as well as research (Burhop, 2010). Regardless of the critical voices regarding this law, 
the creation of new patent protection rules was crucial for the increase in activity in the area of new technologies. Supporting the development of creative know-how led to an increase in quality and building a good brand for German products abroad, while also being a driving force of innovation, especially in railways, and the socalled 'new industries' like the chemical industry (Heggen, 1975), and metallurgy. The act regulating legal aspects in the field of patents contributed to the development of the technology market (Burhop, 2010, p. 923). As Boch adds, the qualitative and quantitative contribution of patented innovations to the German economy has not been studied in detail, which further justifies the attempt undertaken by the author (2017, pp. 252-253).

Despite the above, there is a lack of reliable statistical data on the number of granted patents, including the definition of the so-called valuable patents and often incomplete (fragmentary) data on the level of production. National accounts also hamper the search for the causes of Germany's economic growth in the period of 1872-1913 and limit the extensive use of quantitative methods (Myszczyszyn, 2019, p. 5-6).

In this regard, statistical data became useful which described:

- the level of economic growth of the German Reich estimated by Hoffmann and Müller (1959), Hoffmann (1965), Maddison (2006), and in particular the still little-known estimates of the level of economic growth of the German Reich developed by Burhop and Wolff (2005), the so-called corrected data,

- the numbers of granted patents (Federico, 1964; Statistisches Jahrbuch für das

Deutsche Reich (1880-1916)) and their economically valuable number (Streb, Baten, Yin, 2006).

The main purpose of the article was to identify long-term causality and its direction between the level of economic growth in Germany and the number of granted patents, taking into account economically valuable patents.

Taking into account analyses and papers devoted to explaining economic theories assuming the hypothesis about the positive impact of intellectual property rights on the economic growth, the author verified the research hypotheses (Bielig, 2013, pp. 249-252; Leger, 2005, p. 107; Thumm, 2000):

$\mathrm{H} 1$ - the increase in the number of granted patents, as well as of valuable patents, had a positive effect on the level of Germany's economic growth,

H2 - Germany's economic growth had a positive impact on both the number of granted patents and the number of valuable patents.

Annual data from 1872-1913 was analysed.

In principle, a review of literature in this regard could be summarised by stating that empirical evidence regarding the impact of intellectual property rights, in particular, patents on the economic growth of modern countries, is not unequivocal. One can only conclude that there is no complete consensus in this respect. It should be added that despite the above, it is rather difficult to find works in the field of interdependent studies, including those related to the functioning of patent law at the end of the 19th and the beginning of the 20th century (Myszczyszyn, 2020, pp. 548-563). 


\section{Research methods}

An extremely important issue in economic analyses is the need to combine conclusions regarding short-term dynamics and long-term balance. The traditional approach to modelling short-term imbalances is based on a partial adjustment model, and its development is the error correction model (ECM), taking into account the imbalance in past periods (Maddala, 2006, pp. 622-627). In turn, the long-term versions of economic models correspond to the stationary state (Granger, 1991; McAdam, 1998).

In the case of non-stationary variables, the most common practice is to differentiate them to achieve stationarity. However, model estimation for variable increments does not allow to isolate long-term trends. In this way, only information about the short-term effects of individual variables on the explained variable is obtained, which is a serious limitation in economic analyses.

However, the cointegration relations equation can be successfully used to present the state of long-term balance. Cointegration is usually assessed using the Engle-Granger test or the Johansen method (Johansen, 1988), and depending on the test results the following models can be used in further analyses: VAR (Vector Autoregressive Models), VECM (Vector Error Correction Model), as well as IRF (Impulse Response Function).

Regardless of the method of testing long-term relationships, each of them requires that the analysed variables be integrated to the same order. This is a particularly important premise in economic research, as most of the variables used in economic models are characterised by non-stationary waveforms, which can lead to the establishment of spurious regression and to erroneous conclusions.

The cointegration theory formulated by Granger and developed by Engle and Granger eliminates the main obstacle in modelling the non-stationary series (Engle and Granger, 1987, pp. 251-276).

According to the theory, two processes $y_{t}, x_{t}$ are cointegrated of the order of $(d, b),\left(y_{t}, x_{t} \sim C I(d, b), d \geq b \geq 0\right)$, if:

- the order of integration $d$ of both processes $\left(y_{t}, x_{t}\right)$ is the same;

- there is a linear combination of these processes $u_{t}=\beta_{1} x_{t}+y_{t}$, which is integrated to order $d-b$.

Therefore, it can be written that when $Y_{t} \sim I(d)$ and $X_{t} \sim I(d)$, then $Y_{t}$ and $X_{t} \sim$ $C I(d, b)$, if $y_{t}-\beta x_{t} \sim I(d, b)$, where $b>0$.

This means that the regression equation:

$$
y_{t}=\beta x_{t}+u_{t}
$$

makes sense because $y_{t}$ and $x_{t}$ do not move too much apart over time, and this means that there is a long-term balance between them.

In view of the above, a necessary condition in the study of economic time series is testing for the order of integration of the time series using unit root tests. 
For the analysed interdependence, cointegration occurs if each of the $x_{t}$ and $y_{t}$ time series is integrated of order one (I(1)), i.e. H0 with a unit root is not rejected, and the residuals of $u_{t}$ from the cointegrating equation are not integrated of order (I(1)), that is, $\mathrm{H} 0$ with a unit root is rejected. For this purpose, the following tests can be used: the augmented Dickey-Fuller test (ADF), and the Kwiatkowski-Philips-Schmidt-Shin (KPSS) test (Dickey and Fuller, 1979, pp. 427-431; Kwiatkowski, Phillips, Schmidt, and Shin, 1992, pp. 159-178).

The cointegration study was carried out for variable groups:

1) Germany's economic growth data as a net national product level (NNP (million M.) or Germany's GDP level (million USD);

2) the number of granted patents and the number of valuable patents.

In the case of 1), the author examined seven time series:

a) the net national product (NNP) estimated by Hoffmann (1_NNP_Hoff) (Hoffmann, 1965);

b) corrected by Burhop and Wolff (2005): Compromise NNP (1_NNP_Comp), NNP EH (expenditure method) (1_NNP_EH), NNP IH (revenue method) (1_NNP IH), NNP IHM (income method) (1_NNP_IHM), NNP OH (product method) (1_NNP_OH);

c) the gross domestic product (GDP) estimated by Maddison (1_GDP_Madd).

For 2), the number of granted patents: (1_Pat), the number of valuable patents (1_Pat_HV).

Following generally accepted practice, the data was logged in individual time series (prefix 1_before variables) in order to 'smooth' them (Enders, 2010; Kusidel, 2000; Marona and Bieniek, 2013, pp. 233-350).

The research consisted of the following stages:

- a graphic analysis of the analysed variables;

- a calculation of Pearson correlation coefficients;

- unit root tests: the ADF and KPSS test;

- determining the order of integration of the analysed variables,

- for integrated variables I(1) estimation of the cointegrating equation (Engle-Granger test),

- testing the significance of assessments of the parameters of the cointegration equation,

- determining the residuals of the cointegrating equation,

- unit root tests for the residuals of the cointegrating equation,

- an analysis of the obtained results.

The research was carried out using the GRETL v. 2018a program.

\section{Results}

At the initial stage of the study of individual time series, their course was graphically presented (Figures 1 and 2). 


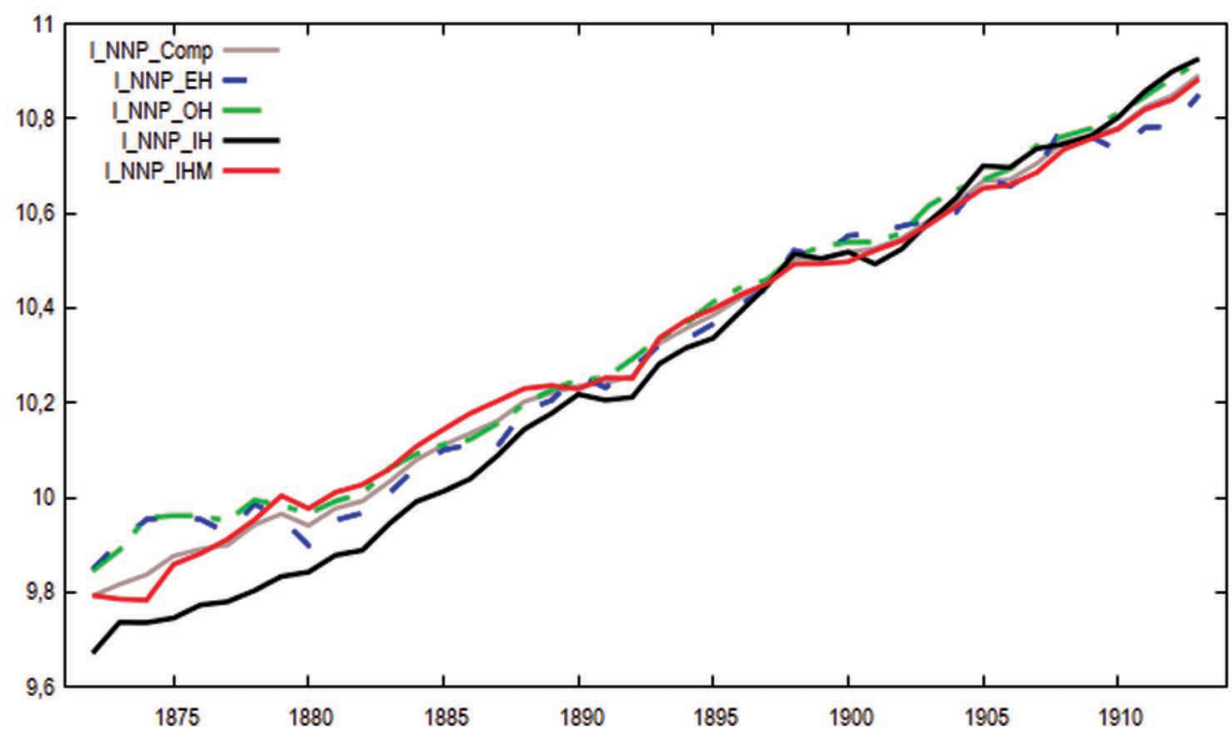

Fig. 1.1_NNP time series for Germany (1872-1913)

Source: author's calculations based on: (Burhop and Wolff, 2005; Hoffmann, 1965; Maddison, 2006).

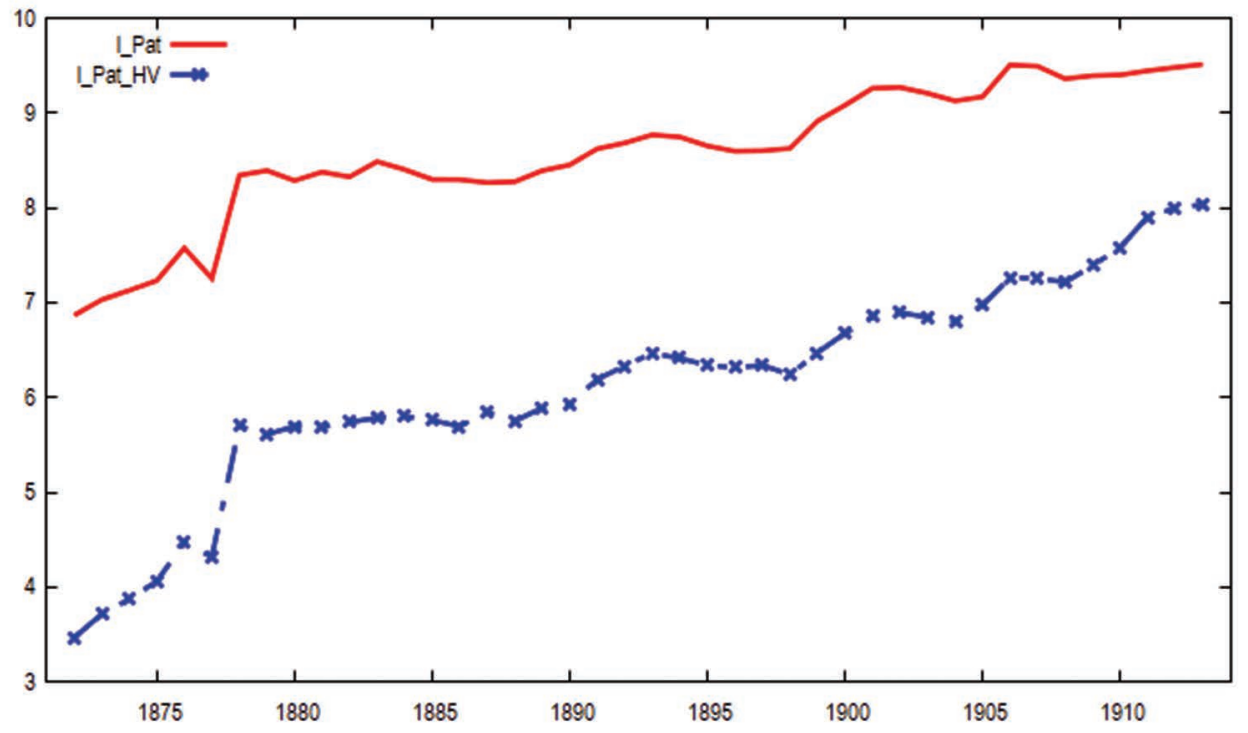

Fig. 2. Number of patents granted (1872-1913) (1_Pat) against the background of the number of valuable patents (1_Pat_HV)

Source: author's calculations based on: (Federico, 1964; Strebb, Wallusch, and Yin, 2007). 
In the analysed years the average annual economic growth, depending on the analysed time series, amounted to:

- NNP Hoffmann - 2.61\%;

- corrected values: a) NNP IHM - 2.64\%; b) NNP EH - 2.54\%; c) NNP IH $3.12 \%$; d) NNP OH $-2.61 \%$; e) compromise NNP- $2.69 \%$;

- $\quad$ GDP Maddison $-2.75 \%$.

The estimated number of granted patents in Germany increased from around 950 in 1872 to nearly 4,500 in 1879 , reaching almost 10,500 in 1901, and 13,500 before the outbreak of World War I. Most patents were issued in the early stages, especially in the metal industry, and including those in the engineering industry. In turn, the chemical industry and the electrotechnical industry successively built their share in granted patents, thanks to which they achieved (1913) the following: in the chemical industry $-11 \%$, and in the electrotechnical industry $-8.4 \%$, while the average annual increase in patents granted in Germany at this time was 3.8\% (Hoffmann, 1965).

It should be added that the amendment to the Act carried out in 1891 regarding the protection of raw materials, regarding in particular the German chemical industry, resulted in an increased number of patents filed during the year by almost $19 \%$ (Fleischer, 1984). In the analysed period the average annual growth rate of registered patents was $5.4 \%$.

The first corporate research and development laboratories were established in the early 1870 s, and a similar phenomenon was only observed in the US at the same time, which mainly concerned the chemical and pharmaceutical industries. The fees for patent protection were high because M 5,300 had to be paid for 15 years of protection, while e.g. in England it was the equivalent of M 3,100 High fees in the German patent system allowed to quickly separate patents with significant economic significance from those of little value, which only contributed to an increase in quality (Burhop, 2010, p. 924).

The author initially relied on the sheer number of patents, regardless of whether it has high or low economic value for the patent proprietor or the public. As noted by Streb et al., one could assess expertly the validity of a given patent for the economy in this regard, at the same time, when analysing the small number of observations, this was relatively easy, but otherwise impossible. In the period analysed by the author, over 300,000 patents were registered, although about $70 \%$ of all German patents granted in 1891-1907 were cancelled after only five years. Hence in their research, Streb et al. assumed that economically valuable patents had a minimum of ten years of duration, and the average share of patents with a high value of all the patents granted in the period 1877-1918 amounted to $11.14 \%$ (Streb, Wallusch, and Yin, 2007, p. 354).

A cursory analysis of the above figures leads to the conclusion that the analysed variables are non-stationary.

Additionally, the correlation coefficients between the 1_Pat and 1_Pat_HV variables and the NNP and GDP series are presented (Table 1). 
Table 1. Pearson correlation coefficients

\begin{tabular}{|l|c|c|c|c|c|c|c|}
\hline Variable & $\begin{array}{c}\text { 1_NNP_- } \\
\text { Comp }\end{array}$ & $\begin{array}{c}\text { 1_NNP_- } \\
\text { EH }\end{array}$ & $\begin{array}{c}\text { 1_NNP_ } \\
\text { OH }\end{array}$ & $\begin{array}{c}\text { 1_NNP_- } \\
\text { IH }\end{array}$ & $\begin{array}{c}\text { 1_NNP_- } \\
\text { IHM }\end{array}$ & $\begin{array}{c}\text { 1_NNP_- } \\
\text { Hoff }\end{array}$ & $\begin{array}{c}\text { 1_GNP } \\
\text { Madd }\end{array}$ \\
\hline 1_Pat & 0.9112 & 0.8829 & 0.8938 & 0.9039 & 0.9246 & 0.8714 & 0.8915 \\
\hline 1_Pat_HV & 0.9289 & 0.8942 & 0.9122 & 0.9219 & 0.9438 & 0.8878 & 0.9086 \\
\hline
\end{tabular}

Source: author's calculations.

The correlation coefficients between the analysed variables confirm that both the 1_Pat and 1_Pat_HV variables are strongly correlated with the variables showing Germany's economic growth.

The lowest correlation coefficient between 1_NNP_Hoff and 1_Pat was 0.8714, as well as 0.9246 for the series $1 \_$NNP_IHM and 1_Pat. Even higher correlation coefficients were noted between individual economic growth data and 1_Pat_HV (the lowest value of 0.8878 , the highest of 0.9289 ).

The high value of the correlation coefficient can exist both when there is cointegration and when there is no cointegration (Czerwińska and Nowak, 2014, pp. 197-198), hence the next step was to examine the order of integration of the studied time series using the augmented Dickey-Fuller test (ADF). It was assumed that the significance level was $\alpha=5 \%$.

Table 2 presents the results of the ADF test for the variables tested. The conclusion is that all analysed time series are non-stationary. At the significance level of $\alpha=5 \%$, there were no grounds to reject the $\mathrm{H} 0$ hypothesis stating that the analysed series is non-stationary. The next step was to perform tests for the first differences.

The time series for the first differences for all analysed variables were stationary, which gives the basis for the conclusion that all the analysed variables were integrated in grade I(1) (Table 2).

Table 2. Residual unit root test results (ADF test)

\begin{tabular}{|l|c|c|c|}
\hline \multicolumn{1}{|c|}{ Variable } & $\begin{array}{c}\text { ADF test for the tested } \\
\text { variables }\end{array}$ & ADF test of the first differences & Conclusion \\
\hline 1_NNP_Comp & 0.9902 & $1.406 \mathrm{e}-006$ & $\mathrm{I}(1)$ \\
\hline 1_NNP_EH & 0.9853 & $19.28 \mathrm{e}-008$ & $\mathrm{I}(1)$ \\
\hline 1_NNP_IHM & 0.9745 & $3.944 \mathrm{e}-007$ & $\mathrm{I}(1)$ \\
\hline 1_NNP_IH & 0.9810 & $8.912 \mathrm{e}-006$ & $\mathrm{I}(1)$ \\
\hline 1_NNP_OH & 0.9957 & $8.208 \mathrm{e}-005$ & $\mathrm{I}(1)$ \\
\hline 1_NNP_Hoff & 0.9830 & $3.718 \mathrm{e}-006$ & $\mathrm{I}(1)$ \\
\hline 1_GDP_Madd & 0.9978 & $2.568 \mathrm{e}-005$ & $\mathrm{I}(1)$ \\
\hline L_Pat & 0.2055 & $5.820 \mathrm{e}-08$ & $\mathrm{I}(1)$ \\
\hline 1_Pat_HV & 0.3661 & $1.057 \mathrm{e}-007$ & $\mathrm{I}(1)$ \\
\hline
\end{tabular}

Source: author's calculations. 
An alternative for testing the unit element was the test with the opposite hypotheses - the KPSS test. The results are shown in Table 3. In the KPSS test, the $\mathrm{HO}$ hypothesis assumed that the series was stationary. If the statistical value of this test was greater than the critical value for the significance level assumed by the author of $\alpha=5 \%$, then there were grounds to reject H0, i.e. to conclude that the time series was non-stationary.

Table 3. The KPSS test for checking the unit root for variables ( $p$ value)

\begin{tabular}{|l|c|c|c|}
\hline \multicolumn{1}{|c|}{ Variable } & $\begin{array}{c}\text { KPSS test for the tested } \\
\text { variables }\end{array}$ & $\begin{array}{c}\text { KPSS test of the first } \\
\text { differences }\end{array}$ & Conclusion \\
\hline \multicolumn{4}{|c|}{ Critical value $(\alpha=5 \%)=0.462$} \\
\hline 1_NNP_Comp & 1.15383 & 0.12930 & $\mathrm{I}(1)$ \\
\hline 1_NNP_EH & 1.14529 & 0.10591 & $\mathrm{I}(1)$ \\
\hline 1_NNP_IHM & 1.14991 & 0.06273 & $\mathrm{I}(1)$ \\
\hline 1_NNP_IH & 1.15188 & 0.08468 & $\mathrm{I}(1)$ \\
\hline 1_NNP_OH & 1.15193 & 0.20013 & $\mathrm{I}(1)$ \\
\hline 1_NNP_Hoff & 1.13874 & 0.15895 & $\mathrm{I}(1)$ \\
\hline 1_GNP_Madd & 1.15023 & 0.27440 & $\mathrm{I}(1)$ \\
\hline 1_Pat & 1.04116 & 0.1986 & $\mathrm{I}(1)$ \\
\hline 1_Pat_HV & 1.05816 & 0.19410 & $\mathrm{I}(1)$ \\
\hline
\end{tabular}

Source: author's calculations.

The unit root studies using the ADF and KPSS tests proved that both the variables regarding Germany's economic growth and the number of granted patents (1_Pat) as well as the number of high-value patents (1_Pat_HV) were non-stationary series. All the analysed series are integrated I(1) (for $\alpha=0.05$ ).

The identical order of integration of the analysed time series enabled the author to conduct a Granger causality test.

In this test, $\mathrm{H} 0$ assumes that the underlying variable does not affect the explained variable. The hypothesis is rejected when the probability (p) of making the term type I error is less than 0.05 .

According to the cointegration method described by Engle and Granger:

- the regression equation for the selected variable describing economic growth relative to the second variable (1_Pat or 1_Pat_HV) was estimated using the classical least squares method (LSM);

- the significance of the estimated equation parameters was examined;

- the regression residuals were determined and the ADF unit root test was used to determine the stationarity of the residuals;

- the assessment was performed.

The results of calculations for individual pairs are presented in Table 4. 
Table 4. Granger causality test results between pairs of variables

\begin{tabular}{|c|c|c|c|c|c|c|c|c|c|}
\hline \# & $\begin{array}{l}\text { Dependent } \\
\text { variable }\end{array}$ & $\begin{array}{l}\text { Independent } \\
\text { variable }\end{array}$ & $\beta$ factor & $\begin{array}{c}T \text {-student } p \\
\text { value }\end{array}$ & $p$ value & $\begin{array}{l}\text { Determi- } \\
\text { nation } \\
\text { factor } \mathrm{R}^{2}\end{array}$ & $\begin{array}{c}\text { ADF test } \\
\text { statistics } \\
\text { of residuals }\end{array}$ & $\begin{array}{c}p \text {-value } \\
\text { of the ADF } \\
\text { test of } \\
\text { residuals }\end{array}$ & $\begin{array}{c}\text { Cointegrating } \\
\text { vector } \\
(\text { Yes/No) }\end{array}$ \\
\hline \multicolumn{10}{|c|}{ Time series of economic growth and the number of valuable patents (1_Pat) } \\
\hline 1. & 1_NNP_Comp & 1_Pat & 0.4186 & \multirow{2}{*}{13.981} & \multirow{2}{*}{0.000} & \multirow{2}{*}{0.8259} & -1.855 & 0.603 & $\mathrm{~N}$ \\
\hline 2. & L_Pat & 1_NNP_Comp & 1.9834 & & & & -2.754 & 0.1806 & $\mathrm{~N}$ \\
\hline 3. & 1_NNP_EH & 1 L_Pat & 0.3865 & \multirow{2}{*}{11.89} & \multirow{2}{*}{0.000} & \multirow{2}{*}{0.774} & -1.8199 & 0.6205 & $\mathrm{~N}$ \\
\hline 4. & 1_Pat & 1_NNP_EH & 2.0169 & & & & -2.7989 & 0.166 & $\mathrm{~N}$ \\
\hline 5. & 1_NNP_IHM & 1_Pat & 0.4164 & \multirow{2}{*}{15.35} & \multirow{2}{*}{0.000} & \multirow{2}{*}{0.8512} & -1.9426 & 0.5579 & $\mathrm{~N}$ \\
\hline 6. & 1_Pat & 1_NNP_IHM & 2.0531 & & & & -2.7605 & 0.1786 & $\mathrm{~N}$ \\
\hline 7. & 1_NNP_IH & 1_Pat & 0.4817 & \multirow{2}{*}{13.36} & \multirow{2}{*}{0.000} & \multirow{2}{*}{0.8124} & -2.0247 & 0.5151 & $\mathrm{~N}$ \\
\hline 8. & 1_Pat & 1_NNP_IH & 1.6962 & & & & -2.9504 & 0.1225 & $\mathrm{~N}$ \\
\hline 9. & 1_NNP_OH & 1_Pat & 0.3996 & \multirow{2}{*}{12.60} & \multirow{2}{*}{0.000} & \multirow{2}{*}{0.7938} & -1.7127 & 0.6723 & $\mathrm{~N}$ \\
\hline 10. & 1_Pat & 1_NNP_OH & 1.9991 & & & & -2.6852 & 0.2049 & $\mathrm{~N}$ \\
\hline 11. & 1_NNP_Hoff & 1_Pat & 0.3936 & \multirow{2}{*}{11.23} & \multirow{2}{*}{0.000} & \multirow{2}{*}{0.7532} & -1.7876 & 0.6364 & $\mathrm{~N}$ \\
\hline 12. & 1_Pat & 1_NNP_Hoff & 1.9289 & & & & -2.7653 & 0.177 & $\mathrm{~N}$ \\
\hline 13. & 1_GDP_Madd & 1_Pat & 0.4209 & \multirow{2}{*}{12.45} & \multirow{2}{*}{0.000} & \multirow{2}{*}{0.7897} & -1.6573 & 0.6976 & $\mathrm{~N}$ \\
\hline 14. & 1_Pat & 1_GDP_Madd & 1.8885 & & & & -2.6805 & 0.2066 & $\mathrm{~N}$ \\
\hline \multicolumn{10}{|c|}{ Time series of economic growth and the number of valuable patents (1_Pat_HV) } \\
\hline 1. & 1_NNP_Comp & 1_Pat_HV & 0.27413 & \multirow{2}{*}{15.86} & \multirow{2}{*}{0.0000} & \multirow{2}{*}{0.8594} & -1.97337 & 0.5419 & $\mathrm{~N}$ \\
\hline 2. & 1_Pat_HV & 1_NNP_Comp & 3.14743 & & & & -2.67936 & 0.2071 & $\mathrm{~N}$ \\
\hline 3. & 1_NNP_EH & 1_Pat_HV & 0.25146 & \multirow{2}{*}{12.63} & \multirow{2}{*}{0.0000} & \multirow{2}{*}{0.7945} & -1.92052 & 0.5694 & $\mathrm{~N}$ \\
\hline 4. & 1_Pat_HV & 1_NNP_EH & 3.17971 & & & & -2.69561 & 0.2011 & $\mathrm{~N}$ \\
\hline 5. & 1_NNP_IHM & 1_Pat_HV & 0.27305 & 1006 & 0 & 00001 & -2.06503 & 0.4939 & $\mathrm{~N}$ \\
\hline 6. & 1_Pat_HV & 1_NNP_IHM & 3.26234 & & 0.0000 & 0.0001 & -2.69049 & 0.203 & $\mathrm{~N}$ \\
\hline 7. & 1_NNP_IH & 1_Pat_HV & 0.31562 & & 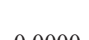 & 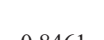 & -2.14191 & 0.4536 & $\mathrm{~N}$ \\
\hline 8. & 1_Pat_HV & 1_NNP_IH & 2.69282 & & & & -2.88304 & 0.1407 & $\mathrm{~N}$ \\
\hline 9. & 1_NNP_OH & 1_Pat_HV & 0.26202 & 1408 & م 0000 & 0 828 & -1.889 & 0.5856 & $\mathrm{~N}$ \\
\hline 10. & 1_Pat_HV & 1_NNP_OH & 3.17597 & 14.00 & 0.0000 & & -2.66593 & 0.212 & $\mathrm{~N}$ \\
\hline 11. & 1_NNP_Hoff & 1_Pat_HV & 0.257657 & 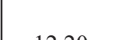 & & & -1.85725 & 0.6017 & $\mathrm{~N}$ \\
\hline 12. & 1_Pat_HV & 1_NNP_Hoff & 3.05906 & & & & -2.6532 & 0.2168 & $\mathrm{~N}$ \\
\hline 13. & 1_GDP_Madd & 1_Pat_HV & 0.27555 & 1276 & م & 00211 & -1.84206 & 0.6094 & $\mathrm{~N}$ \\
\hline 14. & 1_Pat_HV & 1_GDP_Madd & 2.99599 & 15.70 & 0.0000 & 0.0212 & -2.6648 & 0.2124 & $\mathrm{~N}$ \\
\hline
\end{tabular}

Source: author's calculations.

If the ADF test showed that the residuals of the model were stationary, then the vector would be a cointegrating factor. 
On the basis of the Granger causality tests for individual variable pairs, the longterm relationship for all the analysed equations was not confirmed.

The estimated LSM parameters of the cointegrating equation, along with the analysis of residuals at the adopted significance level of $\alpha=0.05$, lead to the conclusion that there are no grounds for rejecting the null hypothesis, therefore the residuals from the cointegrating equation are not stationary. This means that there is no cointegration between variables and their relationship cannot be described in the form of an error correction model.

The results of the applied cointegration tests clearly indicate the lack of any cointegration relationships between the examined pairs of variables.

According to Granger's theorem on representation, if variables $x_{t}$ and $x_{t}$ are integrated (I(1)) and are not integrated, then the relationship between them can only be of a short-term nature.

\section{Conclusion}

The cointegration study of economic variables, usually non-stationary, is of fundamental importance for conducting further analyses, including determining longterm correlations between variables and drawing correct conclusions on their basis.

Engle and Granger's cointegration method, although simple, can give tangible results in establishing the correlation between the analysed time series for non-stationary variables, but all variables were of the same order of integration (I(1)).

Studies have shown that there was no long-term relationship between economic growth (seven time series) and the number of granted patents as well as the number of valuable patents, despite the high correlation coefficients between the analysed variables.

The research did not confirm the causality towards the economic growth of the number of granted patents and showed no causality towards the number of granted patents, i.e. economic growth. Interestingly, the author reached similar conclusions using, for example, the Johansen test (Myszczyszyn, 2020).

The research results could prove that the lack of patent protection contributed to the faster diffusion of knowledge, copying inventions, as evidenced by the imitation effect that was successfully used in the initial stage of industrialisation in the economy of German states (Bielig, 2013, pp. 84-85,151-159; Myszczyszyn, 2019, pp. 121).

The obtained research results lead to the rejection of the hypotheses assumed by the author: H1 and H2. Despite the rejection of the assumed hypotheses about long-term interdependence, the author's study should be treated as a starting point for further analysis using a larger number of variables and using the Johansen tests and VAR models.

It should be added that it is worth considering the correlation between the number of granted patents and valuable patents, differentiating their impact on individual strong growth sectors such as railways, chemical and the electrochemical industries (cf. Streb, Wallusch, and Yin, 2007). 


\section{References}

Bielig, A. (2013). Die Rolle des Geistigen Eigentums in der Wirtschaft. Teorie und Praxis. Warsaw: Warsaw School of Economic.

Boch, R. (2017). Arbeiter - Wirtschaftsbürger - Staat: Abhandlungen zur Industriellen Welt. Berlin/ Boston: Walter de Gruyter GmbH.

Burhop, C. (2010). The transfer of patents in imperial Germany. The Journal of Economic History. 70(4), 921-939.

Burhop, C., and Wolff, G. B. (2005). A compromise estimate of German net national product 1851-1913, and its implications for growth and business cycles. Journal of Economic History, 65(621).

Burhop, C., and Wolff G. B. (2013). The German market for patents during the "Second Industrialization," 1884-1913: A gravity approach. Business History Review, 69-93.

Czerwińska T., and Nowak A. (red.). (2014). Rynek kapitatowy wobec wyzwań dekoniunktury. Warszawa: Wyd. Wydziału Zarządzania UW.

Dickey, D. A., and Fuller, W. (1979). Distribution of the estimators for autoregressive time series with a unit root. Journal of the American Statistical Association, (74), 427-431.

Enders, W. (2010). Applied econometric time series. New York: Willey.

Engle, R. F. and Granger, C. W. J. (1987). Co-integration and error correction: Representation, estimation, and testing. Econometrica, 55(2), 251-276.

Federico, P. J. (1964). Historical patent statistics 1791-1961. Journal of the Patent Office Society, 46(2), 89-171.

Fleischer, A. (1984). Patentgesetzgebung und Chemisch-Pharmazeutische Industrie im Deutschen Kaiserreich (1871-1918). Stuttgart: Deutscher Apotheker Verlag.

Granger, C. W. J. (1991). Developments in the Study of Cointegrated Economic Variables. In R. F. Engle, C. W. J. Granger, Long-Run Economic Relationship, Readings in Cointegration. Oxford: Oxford University Press.

Heggen, A. (1975). Erfindungsschutz und Industrialisierung in Preussen: 1793-1877. In Studien zur Naturwissenschaft. Technik und Wirtschaft im neunzehnten Jahrhundert, Vandenhoeck und Ruprecht. Göttingen.

Hoffmann, W. (1965). Das Wachstum der deutschen Wirtschaft seit der Mitte des 19. Jahrhunderts. Berlin: Springer-Verlag.

Hoffmann, W., and Müller, J. (1959). Das Deutsche Volkseinkommen 1851-1957. Tübingen: Mohr.

Johansen, S. (1988). Statistical analysis of cointegration vectors. Journal of Economic Dynamics and Control, 12(3), 231-54.

Kusideł, E. (2000). Modelowanie wektorowo-autoregresyjne VAR. Metodologia i zastosowanie w badaniach ekonomicznych. Łódź: Absolwent.

Kwiatkowski, D., Phillips, P. C. B., Schmidt, P., and Shin, Y. (1992). Testing the null hypothesis of stationarity against the alternative of a unit root. Journal of Econometrics, 54, 159-178.

Leger, A. (2005). Intellectual Property Rights and their impacts in developing countries. An empirical analysis of Maize Breeding in Mexico. ICAR Discussion Paper, (5).

Maddala, G. S. (2006). Ekonometria. Warszawa: PWN.

Maddison, A. (2006). Historical statistics for the world economy: 1-2003 AD. Retrieved December 12, 2015 from https://www.rug.nl/ggdc/historicaldevelopment/maddison

Majsterek, M. (2008). Wielowymiarowa analiza kointegracyjna w ekonomii. Łódź: Wyd. UŁ.

Marona, B., and Bieniek A. (2013). Wykorzystanie modelu VECM do analizy wpływu bezpośrednich inwestycji zagranicznych na gospodarkę Polski w latach 1996-2010. Acta Universitatis Nicolai Copernici, Ekonomia XLIV, (2), 333-350.

McAdam, P. (1998). A pedagogical note on the long run of macroeconomic models. Kent: University of Kent. 
Metz, R., and Watteler, O. (2002). Historische Innovationsindikatoren Ergebnisse einer Pilotstudie. Historical Social Research, 27(1), 4-99.

Myszczyszyn, J. (2011). Niemiecki Związek Celny (Deutscher Zollverein) i koleje żelazne a rozwój gospodarczy Niemiec w XIX w. - próba oceny. Kultura i Historia 19/2011. Retrieved from http:// www.kulturaihistoria.umcs.lublin.pl/numery/,kultura-i-historia”-nr-192011

Myszczyszyn, J. (2019). Wykorzystanie analizy kliometrycznej w ocenie wpływu kolei żelaznych na wzrost gospodarczy Niemiec. Szczecin: Wyd. Zachodniopomorski Uniwersytet Technologiczny w Szczecinie,

Myszczyszyn, J. (2020). The long-term relationships between the number of patents and economic growth. European Research Studies Journal, XXIII(3), 548-563.

Statistisches Jahrbuch für das Deutsche Reich. (1880-1916). Berlin: Herausgegeben vom Kaiserlichen Statistischen Amt.

Streb, J., Baten, J., and Yin, S., (2006). Technological and geographical knowledge spillover in the German Empire 1877-1918. Economic History Review, LIX(2), 347-373.

Streb, J., Wallusch, J., and Yin, S. (2007). Knowledge spill-over from new to old industries: The case of German synthetic dyes and textiles (1878-1913). Explorations in Economic History, 44, 203-223.

Thumm, N. (2000). Intellectual property rights. National systems and harmonisation in Europe, contribution to economics. Heidelberg.

Tilly, R. (1990). Vom Zollverein zum Industriestaat. Die wirtschaftlich-soziale Entwicklung

Deutschlands 1834 bis 1914. München: Deutscher Taschenbuch Verlag.

\section{ANALIZA KOINTEGRACJI POMIĘDZY WZROSTEM GOSPODARCZYM A LICZBĄ OTRZYMANYCH PATENTÓW}

Streszczenie: Głównym celem artykułu było wykorzystanie testu kointegracji Grangera do potwierdzenia długoterminowych relacji między poziomem wzrostu gospodarczego Niemiec a liczbą otrzymanych patentów, łącznie z uwzględnieniem tzw. wartościowych dla gospodarki patentów. Analizę empiryczną oparto na dostępnych danych statystycznych dotyczących poziomu wzrostu gospodarczego (siedem szeregów czasowych) oraz liczby otrzymanych patentów oraz wartościowych patentów w okresie 1872-1913. Obok szacunków współczynników korelacji Pearsona zastosowano testy na sprawdzenie pierwiastka jednostkowego: ADF i KPSS. Testy wskazały, że wszystkie analizowane szeregi czasowe są zintegrowane w stopniu pierwszym I(1), co umożliwiło użycie testu kointegracji Engle'a-Grangera. Otrzymane wyniki badań nie potwierdziły długookresowej współzależności między poziomem wzrostu gospodarczego w Niemczech a liczbą otrzymanych patentów, w tym tzw. patentów gospodarczo-wartościowych.

Słowa kluczowe: kointegracja Engle'a-Grangera, otrzymane patenty, wzrost gospodarczy Niemiec. 